Review Article

\title{
Loop-mediated isothermal amplification (LAMP) : A rapid molecular diagnosistechnique for detection of human pathogens
}

\author{
Gunimala Chakraborty', Indrani Karunasagar', Anirban Chakraborty ${ }^{3 *}$ \\ ${ }^{1}$ DST women scientist, Division of Infectious Diseases, Nitte University Centre for Science Education and Research Paneer \\ Campus, ${ }^{2}$ Director (R\&D), Dean, Faculty of Biological Sciences, ${ }^{3}$ Deputy Director, Nitte University Centre for Science \\ Education and Research, Nitte University, Mangalore, Karnataka, India.
}

*Corresponding Author : Anirban Chakraborty, Deputy Director, Nitte University Centre for Science Education and Research, Nitte University, M angalore, Karnataka, India.

Mobile: +917022129624 E-mail : anirban@ nitte.edu.in.

$\begin{array}{ll}\text { Received } & : 27.03 .2017 \\ \text { Review Completed } & : 21.08 .2017 \\ \text { Accepted } & : 23.08 .2017\end{array}$

Keywords: Infectious Pathogens, LAMP, DNA, I sothermal Amplification, Molecular Techniques

\begin{tabular}{|c|}
\hline Access this article online \\
\hline Quick Response Code \\
\hline
\end{tabular}

\begin{abstract}
Delivery of quality healthcare in case of an infectious disease depends on how efficiently and how quickly the responsible pathogens are detected from the samples. M olecular methods can detect the presence of pathogens in a rapid and sensitive manner. Over the years, a number of such assays have been developed. However, these methods, although highly reliable and efficient, require use of expensive equipment, reagents, and trained personnel. Therefore, development of molecular assays that are simple, rapid, cost-effective, yet sensitive, is highly warranted to ensure efficient management or treatment strategies. Loop-mediated isothermal amplification (LAMP), a technique invented in the year 2000, is a novel method that amplifies DNA at isothermal conditions. Since its invention, this technique has been one of the most extensively used molecular diagnostic tools in the field of diagnostics offering rapid, accurate and cost-effective diagnosis of infectious diseases. Using the LAM P principle, many commercial kits have been developed in the last decade for a variety of human pathogens including bacteria, viruses and parasites. Currently LAM P assay is being considered as an effective diagnostic tool for use in developing countries because of its simple working protocol, allowing even an onsite application. The focus of this review is to describe the salient features of this technique the current status of development of LAMP assays with an emphasis on the pathogens of clinical significance.
\end{abstract}

\section{Introduction}

The characterization of pathogens from clinical samples is often time consuming and tedious because it requires multiple steps such as enrichment, growth in selective media, and finally biochemical and/or serological identification. In recent years, due to the advancement in molecular biology, a number of alternative techniques have been developed for rapid and sensitive detection of pathogens ${ }^{(1-9)}$ However, these methods, although highly reliable and efficient, require use of expensive equipment, reagents, and trained personnel. Therefore, the need of the hour is to employ the tools and techniques of modern molecular biology towards developing assays that are simple, rapid, cost-effective, yet sensitive. Such assays hold tremendous potential as they can support and strengthen the surveillance and monitoring systems of important pathogens very effectively, particularly in economically backward countries, where the majority of the population are susceptible to the infection by pathogenic organisms due to compromised healthcare systems and lack of general awareness on hygiene and safety.

Among the various molecular techniques, available at present, polymerase chain reaction (PCR)-based detection is considered the gold standard in molecular diagnostics and there are a number of such assays that have commercial applications in routine diagnosis of infectious agents. However, this requires a thermo cycler and a system to detect amplification products. Conventional PCR is being replaced by real-time PCR due to higher sensitivity and ability to detect products in real-time. But this requires expensive equipment. $A$ technique that has shown great 
promise in the field of molecular diagnostics is known as loop-mediated isothermal amplification (LAM P), a method of nucleic acids amplification under isothermal conditions ${ }^{(10)}$. The most distinctive advantages of this technology over the widely used conventional technique to amplify DNA (PCR-based techniques) are its simplicity and its rapidity. LAM P relies on an auto-cycling strand displacement DNA synthesis by Bst DNA polymerase with a set of four specific primers that recognizes a total of six distinct sequences on the target DNA ${ }^{(10)}$. Isothermal amplification generates many different sizes of stem-loop DNAs containing several inverted repeats of the target sequence. When visualized by agarose gel electrophoresis, these stem-loop DNAs appear as several bands of different sizes in a single well. The amplification of LAMP products can also be determined visually by observing the turbidity generated from white precipitate of magnesium pyrophosphate during the strand displacement, either by naked eye or under UV light when stained with SYBR green 1, or by real time monitoring by Loop amp Turbidi meter.

\section{Principle of LAMP}

LAM P, as the name implies, generates multiple copies of a DNA segment at a constant temperature identified by a set of at least four specific primers using a DNA polymerase that possesses the ability of displacing the synthesised strand, which then becomes the template for the next set of amplification ${ }^{(10,11)}$. In principle, a forward inner primer containing both sense and antisense sequences of a part of the target DNA region binds and allows the synthesis of the first strand in the LAMP process. Once the first strand is synthesised, the outer forward primer binds and the polymerase displaces the strand. Since the displaced strand contains complementary sequences of the original strand, a stem-looped DNA structure is formed at one end of this strand. This initiates a process in which a backward inner primer hybridizes to the other end of the synthesised strand and results in strand displacement by a backward outer primer to form a dumbbell shape, which means stem-loop structure at both ends of the amplified DNA. This process continues in subsequent LAMP cycles resulting in final products of multiple stem-looped DNAs ${ }^{11}{ }^{11}$
14). Unlike PCR where only a set of primers is sufficient to amplify a segment of DNA, the LAM P process require four basic primers, which are absolutely critical for loop formation. This ensures high specificity and no amplification is possible in absence of any of the four primers.

\section{Primer design}

The performance of LAMP technique depends on a very precise crafting of four specially designed primers. As shown in Figure 1, the primers are F3 (Forward outer), B3 (Backward outer), FIP (Forward inner) and BIP (Backward inner) primers. These primers recognize a total of six distinct nucleotide sequences (B1, B2, B3, F1, F2, and F3) on the target gene. The $\mathrm{F} 3$ and $\mathrm{B} 3$ play a role in strand displacement and are called as strand displacing primers whereas the inner primers FIP and BIP help in loop formation ' 15 ' The FIP and BIP are designed based on six target regions present on the gene: $F 3 C, F 2 C$, and F1C which are in $3^{\prime}$ side and B1, B2, B3 in the $5^{\prime}$ side of the DNA. In addition to these four specific primers, two more primers called loop primers (LF, Loop forward and LB, Loop backward) can also be incorporated to accelerate the LAMP reaction ' 13 '. Uses of loop primers can reduce the time required to half, and make it a time-saving rapid and efficient diagnostic method. The primers are designed using the Primer explorer software, version 4 (http://primerexplorer.jp/elamp4.0.0/index.html).

\section{Basic working protocol of LAMP}

LAMP uses Bst DNA polymerase, a polymerase that possesses strand displacement activity. Usually, the presence of target DNA is monitored at isothermal conditions between $60^{\circ} \mathrm{C}$ and $65^{\circ} \mathrm{C}$, which is the optimum temperature for Bst DNA polymerase. The temperatures at which the LAM P products show better resolution (intensity of the bands) are selected as the optimum temperature. Similarly, the optimization of the reaction length of LAMP assays involves performing LAM P assays between $15 \mathrm{~min}$ and $120 \mathrm{~min}$ at the optimum temperature with a $15 \mathrm{~min}$ difference between each time point. The time point at which maximum detection levels are reached are 
considered the optimum reaction time for the assay. Denaturation of the template DNA is carried out for $5 \mathrm{~min}$ at $95^{\circ} \mathrm{C}$ before starting the LAMP reaction for isothermal amplification ${ }^{(10)}$ and this step can also be avoided by directly using the non-denatured templates ${ }^{(14) .}$ Incubation is carried out at $58-65^{\circ} \mathrm{C}$ for $45-60 \mathrm{~min}$, and the reaction is terminated by heating at $80^{\circ} \mathrm{C}$ for $2-10 \mathrm{~min}$.

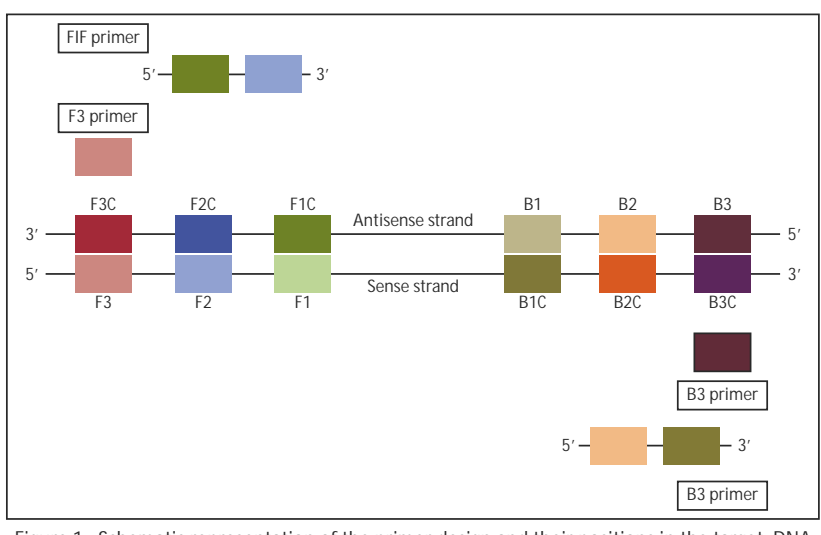

Figure 1 : Schematic representation of the primer design and their positions in the target DNA Figure 1 : Schematic representation of the primers in the target gene. The boxes indicates the primers and their positions.

\section{Basic working protocol of LAM P}

LAMP uses Bst DNA polymerase, a polymerase that possesses strand displacement activity. Usually, the presence of target DNA is monitored at isothermal conditions between $60^{\circ} \mathrm{C}$ and $65^{\circ} \mathrm{C}$, which is the optimum temperature for Bst DNA polymerase. The temperatures at which the LAM P products show better resolution (intensity of the bands) are selected as the optimum temperature. Similarly, the optimization of the reaction length of LAMP assays involves performing LAM P assays between $15 \mathrm{~min}$ and $120 \mathrm{~min}$ at the optimum temperature with a $15 \mathrm{~min}$ difference between each time point. The time point at which maximum detection levels are reached are considered the optimum reaction time for the assay. Denaturation of the template DNA is carried out for $5 \mathrm{~min}$ at $95^{\circ} \mathrm{C}$ before starting the LAMP reaction for isothermal amplification ${ }^{\left({ }^{10)}\right.}$ and this step can also be avoided by directly using the non-denatured templates ${ }^{(14) .}$ Incubation is carried out at $58-65^{\circ} \mathrm{C}$ for $45-60 \mathrm{~min}$, and the reaction is terminated by heating at $80^{\circ} \mathrm{C}$ for $2-10 \mathrm{~min}$.

\section{End-product visualization}

Agarose gel electrophoresis is most commonly used method for end-product visualization wherein the loop DNA's appearing as several bands of different sizes in a single well. Simple visual detection is possible by observing the turbidity derived from the white precipitate of magnesium pyrophosphate generated during the strand displacement by naked eye, or under UV light as bright fluorescence derived from calcein in presence of manganese ions, or in real-time (every $6 \mathrm{sec}$ ) by Loop amp Turbidi meter ${ }^{(16)}$.The different methods of end product visualization are shown in Figure 2.

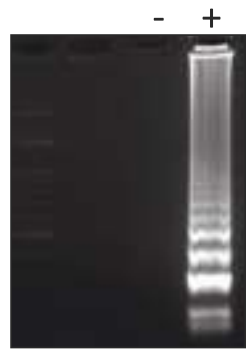

A. Agarose gel electrophoresis

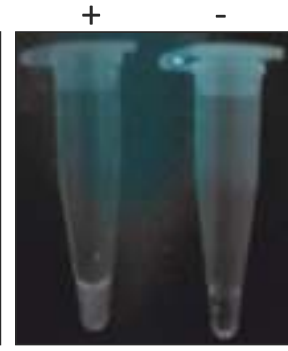

B. Turbidity detection

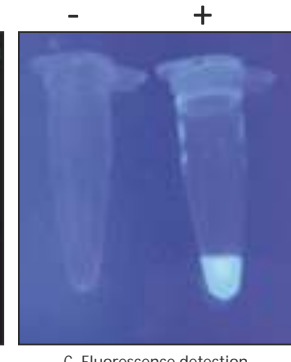

C. Fluorescence detection
Figure 2 : End product visualization of LAM P technique.

\section{Status of LAM P applications in disease diagnosis}

Since the first report in 2000, Loop-mediated isothermal amplification (LAMP) method has attracted a lot of attention around the world, largely due to its potential as a rapid, accurate, and cost-effective molecular diagnostic tool. The technique was first developed in Japan ${ }^{(10)}$ but over the years, researchers in many countries have improvised on the basic protocol and developed various advanced versions of LAMP assays such as reverse transcription LAM P, six primers LAM P, real time Q-LAM P, and M ultiplex LAM P. LAM P-based detection methods are now available for a number of bacterial, viral, and parasitic pathogens of humans and many kits have been commercialized ${ }^{(17)}$. M ore recently, LAM P protocol has been approved as an in vitro diagnostic (IVD) tool and adopted as the officially recommended method for routine identification and surveillance in Japan. Currently, LAMP kits for IVD are available for eight pathogens in Japan. These include, Severe Acute Respiratory Syndrome (SARS) coronavirus, Mycobacterium tuberculosis (TB), Mycoplasma pneumonia, Legionella species, influenza type A virus, $\mathrm{HI}$ 
pdm 2009 influenza virus, H5 influenza virus, and human papilloma virus (HPV) ${ }^{(18)}$. A comprehensive list of LAMP assays developed for human pathogens are shown in Table 1-3.

Table 1 : LAM P detection assays developed for bacterial pathogens

\begin{tabular}{|c|c|}
\hline \multicolumn{2}{|c|}{ Bacterial Pathogens } \\
\hline Species & References \\
\hline M ycobacterium tuberculosis & $\begin{array}{l}\text { Pandeyet al,2008 }{ }^{18}, \\
\text { Geojithet al, } 2011^{19}\end{array}$ \\
\hline $\begin{array}{l}\text { Legionella spp \&Legionella } \\
\text { pneumophila }\end{array}$ & Lu X1 etal,2011 ${ }^{20}$ \\
\hline Staphylococcus aureus & Limet al, $2013^{21}$ \\
\hline Leptospirosis / Leptospira & $\begin{array}{l}\text { Sonthayanonet al, } 2011^{22} \text {, } \\
\text { Hua-Wei Chen, } 2015^{23} \\
\text { Koizumi N etal } 2005^{24}\end{array}$ \\
\hline Listeria monocytogenes & Tanget al, 2011 \\
\hline Bacillus anthracis & Hatanoet al, $2010^{26}$ \\
\hline Vibrio cholerae & Yamazakiet al, 2008 27 \\
\hline Clostridium difficile & Boyantonet al, $2012^{28}$ \\
\hline Candidiosis & Inacio etal $2008^{29}$ \\
\hline Yersinia enterocolitica & $\begin{array}{l}\text { Reza Ranjbar and Davoud } \\
\text { Afshar }^{30}\end{array}$ \\
\hline $\begin{array}{l}\text { Human/Animal Brucellaspp } \\
\text { Bacteria }\end{array}$ & Song L etal, $2012^{31}$ \\
\hline $\begin{array}{l}\text { Human/Animal Escherichia } \\
\text { coli Bacteria }\end{array}$ & Hill J etal, $2008^{32}$ \\
\hline Human/Animal Trypanosoma spp & Thekisoe OM etal, $2007^{33}$ \\
\hline Human Giardia duodenalis & Plutzer Jetal, $2009^{34}$ \\
\hline Human Schistosma mansoni & Fernandez-Soto Petal,2014 35 \\
\hline HumanPlasmodium falciparum & $\begin{array}{l}\text { Najafazadi ZGetal, } 2014^{36} ; \\
\text { Poon LLM etal, } 2006^{37}\end{array}$ \\
\hline Human Leishmania spp & Khan M Getal, $2012^{38}$ \\
\hline $\begin{array}{l}\text { Human/Animal Campylobacter } \\
\text { spp }\end{array}$ & Yamazaki W, $2013^{39}$ \\
\hline Rickettsia spp & Nozomu Hanaoka etal, $2017^{40}$ \\
\hline
\end{tabular}

\section{Status of LAM P in India}

During the initial phase of development, LAMP has been applied to many kinds of pathogens causing food-borne

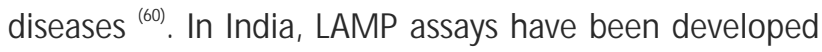
mainly for infectious viruses such as chikungunya virus, Japanese encephalitis virus, west Nile, and dengue virus ${ }^{(46)}$. We, at Nitte University, are developing LAMP assays for major food borne bacterial and viral pathogens associated with gastroenteritis. We have already developed LAMP assays for detection of Salmonella typhi and Staphylococcus aureus. We are now working on LAMP based detection of Shigella spp. and pathogenic E. coli.
Table 2 : LAM P detection assays developed for viral pathogens:

\begin{tabular}{|c|c|}
\hline Species & References \\
\hline H5 influenza virus & $\begin{array}{l}\text { Shanthi Jayawardena etal, } \\
2007^{41}\end{array}$ \\
\hline Human papilloma virus (HPV & Hagiwara M etal,2007² \\
\hline Chikungunya virus & M. M. Parida etal, $2007^{43}$ \\
\hline Japanese encephalitis virus & $\begin{array}{l}\text { Toriniwa H \& Komiya T, } \\
2006^{44} \text {; } \\
\text { M. M. Paridal etal, } 2006^{45}\end{array}$ \\
\hline Dengue virus & $\begin{array}{l}\text { M.M Parida etal, } \\
2006^{46} \text {;;Teoh BT etal, } 2013^{47}\end{array}$ \\
\hline West Nile & $\begin{array}{l}\text { M.M Parida etal, } \\
2004^{48} ; \text { Shukla J1 etal, } 2012^{49}\end{array}$ \\
\hline H1N1 Swine flu & Kuboet al, $2010^{50}$ \\
\hline Human Hepatitis B virus & M oslemi E etal $2009^{51}$ \\
\hline Influenza A Viruses & Leo Letal, $2005^{52}$ \\
\hline Human Rubella virus & Abo H, $2014^{53}$ \\
\hline $\begin{array}{l}\text { Human Norovirus Virus (RNA) } \\
{[69]}\end{array}$ & Fukuda S etal,2006 $6^{54}$ \\
\hline Enterovirus & Xia etal, $2011^{55}$ \\
\hline $\begin{array}{l}\text { Hepatitis C virus (HCV) genotypes } \\
1-6\end{array}$ & $\begin{array}{l}\text { Dougbeh-chris Nyan \& Kevn } \\
\text { L.Swinson } 2016^{56}\end{array}$ \\
\hline
\end{tabular}

Table 3 : LAM P detection assays developed for parasites

\begin{tabular}{|l|l|}
\hline Species & References \\
\hline Cysticercosis (Taenia species) & Nkouawaet al, 2010 ${ }^{57}$ \\
\hline Strongyloides stercolaris & Pedro Fernández-Soto etal \\
& $2016^{58}$ \\
\hline Plasmodium spp & Yee-Ling Lau etal $2016^{59}$ \\
\hline
\end{tabular}

\section{Conclusion}

Effective management of any endemics requires three important steps: diagnosis, surveillance/monitoring and prevention/treatment. Diagnosis is the first critical step of disease management. Therefore, development of a sensitive diagnostic tests is very much important and often a limiting step in successful management of infectious diseases. Loop mediated isothermal amplification (LAM P) is a rapid and cost-effective molecular technique that has been utilized for detecting many important pathogens affecting humans. The pace at which the LAM P has been developed for various infectious agents of medical and veterinary importance in the last decade, is a testimony to the potential this technique has and the advantages it holds over other molecular methods. A very precise primer design is a pre-requisite for the use of LAMP. Recent development in the field of molecular biology and biotechnology has made primer designing simpler. 
However, the chances of false positivity in a LAM P reaction exist and extensive standardization is necessary before commercializing the developed assays. LAMP is more sensitive and specific when compared to PCR.It has been recommended by both WHO and Office des International Epizootics (OIE) for detection of viral diseases and is an integral part of the pen-side diagnosis. LAM P protocol has also been approved as an IVD tool and has been adopted as the officially recommended method for routine identification and surveillance in Japan. In LAMP, the reactions can be performed and results can be read without the need of expensive equipment. A simple heat block is enough to perform a LAM P reaction. Thus, LAMP has great potential for clinical diagnosis in developing countries, where resources are scare and the population are exposed to infectious diseases due to non-adherence to strict hygienic practices, especially in rural areas. In this regard, lyophilised LAM P kits which can be stored at room temperature, which have already been developed and are being marketed by commercial entities.

\section{Reference}

1. Saiki RK, Scharf S, Faloona F, M ullis KB, Horn GT, Erlich HA, Arnheim $\mathrm{N}$. Enzymatic amplification of b-globin genomic sequences and restriction site analysis for diagnosis of sickle cell anaemia. Science. 1985 Dec 20; 230(4732):1350-4

2. Mullis K, Faloona F, Scharf S, Saiki RK, Horn GT, Erlich H. Specific enzymatic amplification of DNA in vitro: the polymerase chain reaction. InCold Spring Harbor symposia on quantitative biology 1986 Jan 1 (Vol. 51, pp. 263-273). Cold Spring Harbor Laboratory Press.

3. Lauerman LH. Advances in PCR technology. Animal health research reviews. 2004 Dec 1; 5(02):247-8.

4. Black EM, Lowings JP, Smith J, Heaton PR, M cElhinney LM . A rapid RTPCR method to differentiate six established genotypes of rabies and rabies-related viruses using TaqMan ${ }^{\mathrm{TM}}$ technology. Journal of virological methods. 2002 Aug 31; 105(1):25-35.

5. Deb R, Chakraborty S. Trends in veterinary diagnostics. Journal of Veterinary Science and Technology. 2012; 3(1).

6. Dhama K, Mahendran M, Tomar S, Thomas P. New generation techniques for detection and characterization of viral pathogens of poultry. Poult. Fortune. 2008; 9(8):32-6.

7. Riaz F, Rashid I,Akbar H, Shehzad W, Islam S, Bajwa AA, Ashraf KSaeed K, DNA Amplification Techniques for the Detection of Toxoplasma gondii Tissue Cysts in Meat Producing Animals: A Narrative Review Article. K ${ }^{1}$ Iran J Parasitol. 2016 Oct-Dec; 11(4):431-440.

8. Singh SD, Barathidasan R, Kumar A, Deb R, Verma AK, Dhama K. Recent trends in diagnosis and control of Marek's Disease (MD) in poultry. Pakistan Journal of Biological Sciences. 2012 Oct 15; 15(20):964.

9. Nath G, M aurya P, Gulati AK. ERIC PCR and RAPD based fingerprinting of Salmonella Typhi strains isolated over a period of two decades. Infection, genetics and evolution. $2010 \mathrm{M}$ ay 31; 10(4):530-6.

10. Notomi T, Okayama H, M asubuchi H, Yonekawa T, Watanabe K, Amino $\mathrm{N}$, Hase T. Loop-mediated isothermal amplification of DNA. Nucleic acids research. 2000 Jun 15; 28(12).
LAM P technique has tremendous application in the field of molecular diagnostics because even a layman, who doesn't possess any prior knowledge about the scientific aspects of DNA amplification, can use thistechnique. An effective use of LAMP would be in clinical settings, particularly in hospitals and primary health centers, where diagnosis can be done within a few hours of patient walking in. It should also be noted that the developed assays should be costeffective yet specific, to make them affordable for the common man in a country like India, where the majority of the population is underprivileged and deprived of tertiary health care.

\section{Acknowledgment}

This study was supported by Department of Science and technology (DST), Government of India under the women scientist scheme (WOS-A) (G). We would like to thank NITTE University for providing the resources and infrastructure for research.

11. Fu S, Qu G, Guo S, Ma L, Zhang N, Zhang S, Gao S, Shen Z. Applications of loop-mediated isothermal DNA amplification. Applied biochemistry and biotechnology. 2011 Apr 1; 163(7):845-50

12. Nagamine K, Watanabe K, Ohtsuka K, Hase T, Notomi T. Loop-mediated isothermal amplification reaction using a nondenatured template. Clinical Chemistry. 2001 Sep 1; 47(9):1742-3.

13. Nagamine K, Hase T, Notomi T. Accelerated reaction by loop-mediated isothermal amplification using loop primers. Molecular and cellular probes. 2002 Jun 30; 16(3):223-9.

14. Nagamine $K$, Kuzuhara $Y$, Notomi T. Isolation of single-stranded DNA from loop-mediated isothermal amplification products. Biochemical and biophysical research communications. 2002 Feb 1; 290(4):1195-8.

15. Parida M, Sannarangaiah S, Dash PK, Rao PV, and Morita K. Loop mediated isothermal amplification (LAMP): a new generation of innovative gene amplification technique; perspectives in clinical diagnosis of infectious diseases. Reviews in medical virology. $2008 \mathrm{Nov}$ $1 ; 18(6): 407-21$

16. Tomita N, Mori Y, Kanda H, Notomi T. Loop-mediated isothermal amplification (LAM P) of gene sequences and simple visual detection of products. Nature protocols. $2008 \mathrm{M}$ ay 1; 3(5):877-82.

17. M ori Y, Notomi T. Loop-mediated isothermal amplification (LAM P): a rapid, accurate, and cost-effective diagnostic method for infectious diseases. Journal of infection and chemotherapy. 2009 Jan 1; 15(2):629 .

18. Mori Y, Kanda H, Notomi T. Loop-mediated isothermal amplification (LAMP): recent progress in research and development. Journal of infection and chemotherapy. 2013 Jan 1; 19(3):404-11.

20. Lu X, M O ZY, Zhao HB, Yan H, Shi L. LAM P-based method for a rapid identification of Legionella spp. and Legionella pneumophila. Applied microbiology and biotechnology. 2011 Oct 1; 92(1):179.

21. Xu Z, Li L, Chu J, Peters BM, Harris ML, Li B, Shi L, Shirtliff ME. Development and application of loop-mediated isothermal 
amplification assays on rapid detection of various types of staphylococci strains. Food Research International. 2012 Jul 31; 47(2):166-73.

22. Sonthayanon P, Chierakul W, Wuthiekanun V, Thaipadungpanit J, Kalambaheti T, Boonsilp S, Amornchai P, Smythe LD, Limmathurotsakul D, Day NP, Peacock SJ. Accuracy of loop-mediated isothermal amplification for diagnosis of human leptospirosis in Thailand. The American journal of tropical medicine and hygiene. 2011 Apr 5; 84(4):614-20.

23. Hua-Wei Chen $2015^{23}$ Chen HW, Weissenberger G, Atkins E, Chao CC, Suputtamongkol Y, Ching WM. Highly sensitive loop-mediated isothermal amplification for the detection of Leptospira. International journal of bacteriology. 2015Jan 27, 23(1).

24. Koizumi N, Nakajima C, Harunari T, Tanikawa T, Tokiwa T, Uchimura E, Furuya T, M ingala CN, Villanueva M A, Ohnishi M, Suzuki Y. A new loopmediated isothermal amplification method for rapid, simple, and sensitive detection of Leptospira spp. in urine. Journal of clinical microbiology. 2012 Jun 1; 50(6):2072-4.

25. Tang MJ, Zhou S, Zhang XY, Pu JH, Ge QL, Tang XI, Gao YS. Rapid and sensitive detection of Listeria monocytogenes by loop-mediated isothermal amplification. Current microbiology. 2011 Dec 1; 63(6):511.

26. Kurosaki Y, Sakuma T, Fukuma A, Fujinami Y, Kawamoto K, Kamo N, Makino SI, Yasuda J. A simple and sensitive method for detection of Bacillus anthracis by loop-mediated isothermal amplification. Journal of applied microbiology. 2009 Dec 1; 107(6):1947-56.

27. Yamazaki W, Seto K, Taguchi M, Ishibashi M, Inoue K. Sensitive and rapid detection of cholera toxin-producing Vibrio cholerae using a loop-mediated isothermal amplification. BM C microbiology. 2008 Jun 12; 8(1):94.

28. Boyanton BL, Sural P, Loomis CR, Pesta C, Gonzalez-Krellwitz L, Robinson-Dunn B, Riska P. Loop-mediated isothermal amplification compared to real-time PCR and enzyme immunoassay for toxigenic Clostridium difficile detection. Journal of clinical microbiology. 2012 Mar 1; 50(3):640-5.

29. Inácio J, Flores 0 , Spencer-M artins I. Efficient identification of clinically relevant Candida yeast species by use of an assay combining panfungal loop-mediated isothermal DNA amplification with hybridization to species-specific oligonucleotide probes. Journal of clinical microbiology. 2008 Feb 1; 46(2):713-20.

30. Reza Ranjbar, Davoud Afshar. Development of a loop -mediated isothermal amplification assay for rapid detection of Yersinia enterocolitica via targeting a conserved locus.Iran J Microbiol. 2015 Aug; 7(4):185-190.

31. Song L, Li J, Hou S, Li X, Chen S. Establishment of loop-mediated isothermal amplification (LAMP) for rapid detection of Brucella spp. and application to milk and blood samples. Journal of microbiological methods. 2012 Sep 30; 90(3):292-7.

32. Hill J, Beriwal S, Chandra I, Paul VK, Kapil A, Singh T, Wadowsky RM, Singh V, Goyal A, Jahnukainen T, Johnson JR. Loop-mediated isothermal amplification assay for rapid detection of common strains of Escherichia coli. Journal of Clinical Microbiology. 2008 Aug 1; 46(8):2800-4.

33. Thekisoe OM , Kuboki N, Nambota A, Fujisaki K, Sugimoto C, Igarashi I, Yasuda J, Inoue N. Species-specific loop-mediated isothermal amplification (LAMP) for diagnosis of trypanosomosis. Acta tropica. 2007Jun 30; 102(3):182-9.

34. Plutzer J, Karanis P. Rapid identification of Giardia duodenalis by loopmediated isothermal amplification (LAMP) from faecal and environmental samples and comparative findings by PCR and realtime PCR methods. Parasitology research. 2009 M ay 1; 104(6):152733.

35. Fernández-Soto P, Arahuetes JG, Hernández AS, Abán JL, Santiago BV Muro A. A loop-mediated isothermal amplification (LAMP) assay for early detection of Schistosoma mansoni in stool samples: a diagnostic approach in a murine model. PLoS Negl Trop Dis. 2014 Sep 4; 8(9):e3126.
36. Najafabadi ZG, Oormazdi H, Akhlaghi L, M eamar AR, Nateghpour M, Farivar L, Razmjou E. Detection of Plasmodium vivax and Plasmodium falciparum DNA in human saliva and urine: Loop-mediated isothermal amplification for malaria diagnosis. Acta Tropica. 2014 Aug 31; 136:449.

37. Poon LL, Leung CS, Chan KH, Lee JH, Yuen KY, Guan Y, Peiris JS. Detection of human influenza A viruses by loop-mediated isothermal amplification. Journal of clinical microbiology. 2005 Jan 1; 43(1):42730

38. Khan MG, Bhaskar KR, Salam MA, Akther T, Pluschke G, M ondal D. Diagnostic accuracy of loop-mediated isothermal amplification (LAM P) for detection of Leishmania DNA in buffy coat from visceral leishmaniasis patients. Parasites \& vectors. 2012 Dec 3; 5(1):280

39. Yamazaki W. Sensitive and rapid detection of Campylobacter jejuni and Campylobacter coli using loop-mediated isothermal amplification. PCR Detection of M icrobial Pathogens. 2013:267-77.

40. Nozomu Hanaoka, Minenosuke M atsutani, Masaaki Satoh, M otohiko Ogawa, M utsunori Shirai, Shuji Ando. Development of a Novel LoopMediated Isothermal Amplification (LAM P) Assay for the Detection of Rickettsia spp. Japanese J ournal of Infectious Diseases Vol. 70 No. 1.

41. Jayawardena S. Loop-M ediated Isothermal Amplification for Influenza A (H5N1) Virus-Volume 13, Number 6-June 2007-Emerging Infectious Disease journal-CDC

42. Hagiwara M, Sasaki H, Matsuo K, Honda M, Kawase M, Nakagawa H. Loop-mediated isothermal amplification method for detection of human papillomavirus type $6,11,16$, and 18 . Journal of medical virology. $2007 \mathrm{M}$ ay 1; 79(5):605-15.

43. M M Parida,S, R SanthoshP K, DashN K, Tripathi V, Lakshmi,N, Mamidi,A, ShrivastvaN, GuptaP, Saxena J, Pradeep Babul_P, V Lakshmana Rao, Kouichi Morita.Rapid and Real-Time Detection of Chikungunya Virus by Reverse Transcription Loop-Mediated Isothermal Amplification Assay.J. Clin. M icrobiol. February 2007 vol. 45 no. 2351-357.

44. Toriniwa H, Komiya T. Rapid detection and quantification of Japanese encephalitis virus by real-time reverse transcription loop-mediated isothermal amplification. Microbiology and immunology. $2006 \mathrm{M}$ ay $1_{\text {; }}$ 50(5):379-87.

45. Parida M M, Santhosh SR, Dash PK, Tripathi NK, Saxena P, Ambuj S, Sahni AK, Rao PL, Morita K. Development and evaluation of reverse transcription-loop-mediated isothermal amplification assay for rapid and real-time detection of Japanese encephalitis virus. Journal of Clinical M icrobiology. 2006 Nov 1; 44(11):4172-8.

46. Teoh BT, Sam SS, Tan KK, Johari J, Danlami M B, Hooi PS, M d-Esa R, AbuBakar $\mathrm{S}$. Detection of dengue viruses using reverse transcriptionloop-mediated isothermal amplification. BMC infectious diseases. 2013 Aug 21; 13(1):387.

47. Parida M, Horioke K, Ishida H, Dash PK, Saxena P, Jana AM, Islam M A, Inoue S, Hosaka N, M orita K. Rapid detection and differentiation of dengue virus serotypes by a real-time reverse transcription-loopmediated isothermal amplification assay. Journal of clinical microbiology. 2005Jun 1; 43(6):2895-903.

48. Parida M. Posadas G, Inoue S, Hasebe F, M orita K. Real-time reverse transcription loop-mediated isothermal amplification for rapid detection of West Nile virus. Journal of clinical microbiology. 2004 Jan 1:42(1):257-63

49. Shukla J, Saxena D, Rathinam S, Lalitha P, Joseph CR, Sharma S, Soni M, Rao PV, Parida M. Molecular detection and characterization of West Nile virus associated with multifocal retinitis in patients from southern India. International Journal of Infectious Diseases. 2012 Jan 31; 16(1):e53-9.

50. Kubo, T., M. Agoh, Q. Le Mai, K. Fukushima and H. Nishimura et al. 2010. Development of a reverse transcription-loop-mediated isothermal amplification assay for detection of pandemic (H1N1) 2009 virus as a novel molecular method for diagnosis of pandemic influenza in resource-limited settings. J. Clin. M icrobiol. 48: 728-735.

51. M oslemi E, Shahhosseiny M H, Javadi G, Praivar K, Sattari TN, Amini HK. Loop mediated isothermal amplification (LAM P) for rapid detection of 
HBV in Iran. African Journal of Microbiology Research. 2009 Aug 31; 3(8):439-45.

52. Leo L. M. Poon1, Cynthia S. W. Leung,Kwok H. Chan, Jack H C Lee, Kwok Y, Yi Guan, Joseph S M Peiris.Detection of Human Influenza A Viruses by Loop-Mediated Isothermal Amplification. J. Clin. Microbiol. January 2005.vol. 43 no. 1427-430.

53. Abo H, Okamoto K, Anraku M, Otsuki N, Sakata M , Icenogle J, Zheng Q, Kurata T, Kase T, Komase K, Takeda M . Development of an improved RTLAMP assay for detection of currently circulating rubella viruses. Journal of virological methods. 2014 Oct 31; 207:73-7.

54. Fukuda S, Takao S, Kuwayama M, Shimazu Y, Miyazaki K. Rapid detection of norovirus from fecal specimens by real-time reverse transcription-loop-mediated isothermal amplification assay. Journal of clinical microbiology. 2006 Apr 1; 44(4):1376-81.

55. Xia J F, X F Yan, H. Yu, D. Qu and J.E. Long, 2011. Simple and rapid detection of human enterovirus 71 by reverse-transcription and loopmediated isothermal amplification: Cryopreservation affected the detection ability. Diagn. M icrobiol. Infect. Dis., 71: 244-251.

56. Dougbeh-Chris Nyan' Kevin L. Swinson. A method for rapid detection and genotype identification of hepatitis $C$ virus $1-6$ by one-step reverse transcription loop-mediated isothermal amplification International,2016Volume 43,(30-36).

57. Nkouawa A, Sako Y, Li T, Chen X, Wandra T, Swastika IK, Nakao M, Yanagida T, Nakaya K, Qiu D, Ito A. Evaluation of a loop-mediated isothermal amplification method using fecal specimens for differential detection of Taenia species from humans. Journal of clinical microbiology. 2010 Sep 1; 48(9):3350-2.

58. Fernández-Soto $P$, Sánchez-Hernández A, Gandasegui J, Santos CB, López-Abán J, Saugar JM, Rodríguez E, Vicente B, Muro A. StrongLAM P: A LAM P Assay for Strongyloides spp. Detection in Stool and Urine Samples. Towards the Diagnosis of Human Strongyloidiasis Starting from a Rodent Model. PLoS Negl Trop Dis. 2016 Jul 14; 10(7):004836

59. Yee-Ling Lau, Meng-Yee Lai, Mun-Yik Fong, Jenarun Jelip, Rohela Mahmud Loop-Mediated Isothermal Amplification Assay for Identification of Five HumanPlasmodiumSpecies in Malaysia. Am J Trop M ed Hyg, 2016 Feb 3; 94(2): 336-339.

60. Lukinmaa S, Nakari U, Eklund M, Siitonen A. Application of molecular genetic methods in diagnostics and epidemiology of food-borne bacterial pathogens. APM IS (2004), 12, 908-929. 